\title{
LATIHAN SOSIALISASI DAN SENAM AEROBIK LOW IMPACT MENINGKATKAN KEMAMPUAN BERSOSIALISASI PADA PASIEN ISOLASI SOSIAL
}

\author{
Madepan Mulia ${ }^{*}$, Lutfie Arief Afiyudin ${ }^{2}$, Rusmala Dewi ${ }^{3}$ \\ 1, 2, ${ }^{3}$ Sekolah Tinggi Ilmu Kesehatan Panca Bhakti Bandar Lampung, Lampung, Indonesia, \\ madepan@pancabhakti.ac.id
}

\begin{abstract}
Abstrak
Skizofrenia adalah gangguan pikiran dan persepsi disertai afek tumpul akibat kerusakan otak. Penelitian ini bertujuan menilai kemampuan bersosialisasi pasien isolasi sosial dengan pemberian latihan sosialisasi dan senam aerobic low impact di Lembaga Kesejahteraan Sosial Mitra Sakti Kabupaten Pesawaran Provinsi Lampung. Metode dalam penelitian menggunakan tindakan keperawatan berupa latihan sosialisasi dan senam aerobic low impact terhadap 5 orang pasien skizofrenia dengan masalah keperawatan isolasi sosial di Lembaga Kesejahteraan Sosial Mitra Sakti Kabupaten Pesawaran Provinsi Lampung yang dilaporkan dalam bentuk studi kasus. Hasil penelitian menunjukkan bahwa setelah diberikan tindakan keperawatan berupa latihan sosialisasi dan senam aerobic low impact pada kelima partisipan terjadi peningkatan kemampuan bersosialisasi. Perawat diharapkan dapat memberikan tindakan keperawatan latihan sosialisasi dan senam aerobic low impact kepada pasien isolasi sosial.
\end{abstract}

Kata kunci $\quad$ : Isolasi sosial, latihan sosialisasi, senam aerobik low impact, skizofrenia.

\begin{abstract}
Schizophrenia is a disorder of thought and perception accompanied by blunted affect due to brain damage. This study aims to assess social interaction skills by providing socialization exercises and low impact aerobics at the Mitra Sakti Social Welfare Institution, Pesawaran Regency, Lampung Province. The method in this research uses actions in the form of socialization exercises and low impact aerobic exercise on 5 patients schizophrenic with social isolation nursing problems at the Mitra Sakti Social Welfare Institution, Pesawaran Regency, Lampung Province reported in case studies. The results showed that after being given the action of increasing socialization and low impact aerobic exercise, the five participants improved their social skills. Nurses are expected to provide socialization care and low impact aerobic exercise to socially isolated patients.
\end{abstract}

Keywords : Low impact aerobic exercise, schizophrenia, social isolation, socialization exercises

\section{PENDAHULUAN}

Menurut World Health Organization (WHO), kesehatan jiwa adalah karakteristik positif yang menunjukkan keselarasan, keseimbangan dan mencerminkan kedewasaan kepribadian. Gangguan jiwa adalah sindrom penyebab yang belum diketahui dan perjalanan

Corresponding author:

Madepan Mulia

madepan@pancabhakti.ac.id penyakit tidak selalu bersifat kronis, ditandai adanya penyimpangan yang fundamental, pada pikiran dan persepsi, serta adanya afek yang tidak wajar atau tumpul (Yusuf, A.H., dkk, 2015). 
World Health Organization (WHO) menyebutkan bahwa penderita gangguan jiwa di dunia pada tahun 2010 sebanyak 450 juta jiwa dimana penderita skizofrenia sebanyak 0,2\% $2 \%$ (kurang lebih 24 juta jiwa). Kasus baru yang muncul tiap tahun sekitar $0,01 \%$ dimana $75 \%$ pasien mengalami skizofrenia pada usia 16-25 tahun (Noviria, M., 2014).

Seseorang yang mengalami skizofrenia biasanya mengalami distorsi pikiran, persepsi, emosi, bahasa, kesadaran diri dan perilaku disertai pengalaman mendengar suara-suara dan delusi. Pasien skizofrenia biasanya menunjukkan gejala positif seperti waham, halusinasi, disorganisasi pikiran dan bicara, perilaku kacau, sedangkan gejala negatifnya berupa afek datar dan menarik diri dari pergaulan masyarakat (Keliat, B.A., 2014).

Isolasi sosial adalah kondisi individu yang mengalami penurunan bahkan tidak mampu berinteraksi dengan orang sekitar ditandai dengan perasaan tidak diterima, ditolak, kesepian dan tidak mampu membina hubungan dengan orang lain (Nurhalimah, 2016).

Tindakan keperawatan yang dapat diberikan pada pasien isolasi sosial adalah dengan latihan bersosialiasi dan senam aerobik low impact. Senam aerobik low impact adalah gerakan aerobik berupa hentakan-hentakan ringan. Hal ini didukung oleh penelitian yang menyatakan bahwa terapi senam aerobik mempengaruhi keterbukaan diri pasien isolasi sosial di Rumah Sakit Jiwa Daerah (RSJD) Dr. Aminogondohutomo Semarang (Astuti, R.W., 2014).

Tujuan penelitian ini adalah mengetahui kemampuan bersosialisasi pasien skizofrenia yang mengalami isolasi sosial dengan penerapan latihan sosialisasi dan senam aerobic low impact di Lembaga Kesejahteraan Sosial Mitra Sakti Kabupaten Pesawaran Provinsi Lampung.

\section{METODE PENELITIAN}

Penelitian ini berupa penelitian kualitatif dengan desain studi kasus (case report). Subjek penelitian adalah 5 partisipan skizofrenia yang mengalami isolasi sosial di Lembaga Kesejahteraan Sosial Mitra Sakti Kabupaten Pesawaran Provinsi Lampung. Penelitian menggunakan instrumen lembar observasi kemampuan bersosialisasi, Standar Operasioal
Prosedur (SOP) latihan sosialisasi dan senam aerobic low impact.

\section{HASIL}

Penelitian ini dilakukan pada 5 partisipan yaitu Tn. S 42 tahun, Tn. R 38 Tahun, Tn. M 36 Tahun, Tn. W 22 Tahun dan Tn. Z 34 Tahun. Berdasarkan hasil pengkajian, kondisi kelima klien mengalami isolasi sosial dengan menunjukkan tanda dan gejala berikut: klien kesulitan memulai pembicaraan, menundukkan kepala, tidak menghadap lawan bicara, menyendiri, tidak mau diganggu, hanya berdiam diri di kamar dan kurang sosialisasi dengan orang sekitar.

\section{Tabel 1}

\section{Kemampuan Bersosialisasi Sebelum Dilakukan Terapi Sosialisasi dan Senam Aerobik Low Impact $(\mathbf{n}=5)$}

\begin{tabular}{ccc}
\hline Klien & $\begin{array}{c}\text { Skor } \\
\text { Kemampuan } \\
\text { Bersosialisasi }\end{array}$ & Kategori \\
\hline Tn. S & 6 & $\begin{array}{l}\text { Tidak Mampu } \\
\text { Bersosialisasi }\end{array}$ \\
\hline Tn. R & 5 & $\begin{array}{l}\text { Tidak Mampu } \\
\text { Bersosialisasi }\end{array}$ \\
\hline Tn. M & 5 & $\begin{array}{l}\text { Tidak Mampu } \\
\text { Bersosialisasi }\end{array}$ \\
\hline Tn. W & 4 & $\begin{array}{l}\text { Tidak Mampu } \\
\text { Bersosialisasi }\end{array}$ \\
\hline Tn. Z & 6 & $\begin{array}{l}\text { Tidak Mampu } \\
\text { Bersosialisasi }\end{array}$ \\
\hline Rata-Rata & 5.2 & $\begin{array}{l}\text { Tidak Mampu } \\
\text { Bersosialisasi }\end{array}$ \\
\hline
\end{tabular}

Berdasarkan tabel 1 diketahui bahwa kemampuan bersosialisasi sebelum diberikan tindakan keperawatan latihan bersosialisasi dan senam aerobic low impact di Lembaga Kesejahteraan Sosial (LKS) Mitra Sakti Kabupaten Pesawaran Provinsi Lampung pada Tn. S skor 6 dengan kategori tidak mampu bersosialisasi, Tn. R skor 5 dengan kategori tidak mampu bersosialisasi, Tn. M skor 5 dengan kategori tidak mampu bersosialisasi, Tn. W skor 4 dengan kategori tidak mampu bersosialisasi, Tn. Z skor 6 dengan kategori tidak mampu bersosialisasi. Rata-rata kemampuan bersosialisasi pada kelima klien sebelum diberikan tindakan keperawatan latihan bersosialisasi dan senam aerobic low impact 
adalah 5,2 dengan kategori tidak mampu bersosialisasi.

\section{Tabel 2}

Kemampuan Bersosialisasi Sesudah Dilakukan Terapi Sosialisasi dan Senam Aerobik Low Impact $(\mathrm{n}=5)$

\begin{tabular}{ccc}
\hline Klien & $\begin{array}{c}\text { Skor } \\
\text { Kemampuan } \\
\text { Bersosialisasi }\end{array}$ & Kategori \\
\hline Tn. S & 12 & $\begin{array}{c}\text { Mampu } \\
\text { Bersosialisasi }\end{array}$ \\
\hline Tn. R & 12 & $\begin{array}{c}\text { Mampu } \\
\text { Bersosialisasi }\end{array}$ \\
\hline Tn. M & 12 & $\begin{array}{c}\text { Mampu } \\
\text { Bersosialisasi }\end{array}$ \\
\hline Tn. W & 10 & $\begin{array}{c}\text { Mampu } \\
\text { Bersosialisasi }\end{array}$ \\
\hline Tn. Z & 12 & $\begin{array}{c}\text { Mampu } \\
\text { Bersosialisasi }\end{array}$ \\
\hline Rata-Rata & 11.6 & $\begin{array}{c}\text { Mampu } \\
\text { Bersosialisasi }\end{array}$ \\
\hline
\end{tabular}

Berdasarkan tabel 2 diketahui bahwa kemampuan bersosialisasi sesudah diberikan tindakan keperawatan latihan bersosialisasi dan senam aerobic low impact di Lembaga Kesejahteraan Sosial (LKS) Mitra Sakti Kabupaten Pesawaran Provinsi Lampung pada Tn. S skor 12 dengan kategori mampu bersosialisasi, Tn. R skor 12 dengan kategori mampu bersosialisasi, Tn. M skor 12 dengan kategori mampu bersosialisasi, Tn. W skor 10 dengan kategori mampu bersosialisasi, Tn. Z skor 12 dengan kategori mampu bersosialisasi. Rata-rata kemampuan bersosialisasi pada kelima klien sesudah diberikan tindakan keperawatan latihan bersosialisasi dan senam aerobic low impact adalah 11,6 dengan kategori mampu bersosialisasi.

\section{PEMBAHASAN}

Tulisan "Pembahasan" diketik dengan huruf Isolasi sosial adalah perasaan kehilangan hubungan dan tidak mempunyai kesempatan untuk berbagi rasa dan pikiran sehingga seseorang menghindari komunikasi dengan orang lain. Selain itu, seseorang yang mengalami
Tabel 3

Perbedaan Kemampuan Bersosialisasi Sebelum dan Sesudah Dilakukan Terapi Sosialisasi dan Senam Aerobik Low Impact $(\mathrm{n}=5)$

\begin{tabular}{cccc}
\hline Klien & \multicolumn{2}{c}{$\begin{array}{c}\text { Skor Kemampuan } \\
\text { Bersosialisasi }\end{array}$} & Selisih \\
& Sebelum & Sesudah & \\
\hline Tn. S & 6 & 12 & 6 \\
\hline Tn. R & 5 & 12 & 7 \\
\hline Tn. M & 5 & 12 & 7 \\
\hline Tn. W & 4 & 10 & 6 \\
\hline Tn. Z & 6 & 12 & 6 \\
\hline Rata-Rata & 5.2 & 11.6 & 6.4 \\
\hline
\end{tabular}

Berdasarkan tabel 3 diketahui bahwa sebelum diberikan tindakan keperawatan latihan bersosialisasi dan senam aerobic low impact di Lembaga Kesejahteraan Sosial (LKS) Mitra Sakti Kabupaten Pesawaran Provinsi Lampung, kemampuan bersosialisasi pada Tn. S adalah 6, sesudah adalah 12 dengan selisih peningkatan kemampuan 6; Tn. R sebelum adalah 5, sesudah adalah 12 dengan selisih peningkatan 7; Tn. M sebelum adalah 5, sesudah adalah 12 dengan selisih peningkatan 7; Tn. W sebelum adalah 4, sesudah adalah 10 dengan selisih peningkatan 6; dan Tn. Z sebelum adalah 6 , sesudah adalah 12 dengan selisih peningkatan 16. Rata-rata kemampuan bersosialisasi pada kelima klien sebelum diberikan tindakan keperawatan latihan bersosialisasi dan senam aerobic low impact adalah 5,2 dengan kategori tidak mampu bersosialisasi, sesudah adalah 11,6 dengan kategori mampu bersosialisasi dengan rata-rata selisih peningkatan kemampuan bersosialisasi adalah 6,4 .

isolasi sosial biasanya merasa sulit berhubungan dengan orang lain secara spontan yang ditandai dengan kurang perhatian, tidak mampu berbagi pengalaman dan berhubungan secara spontan (Yosep, I., 2013).

Seseorang yang mengalami isolasi sosial ditandai dengan perilaku tidak sesuai, afek tumpul, tindakan tidak berarti, kontak mata tidak 
ada, sikap bermusuhan, ingin sendiri, kurang komunikasi, menarik diri dan tidak ada dukungan orang yang dianggap penting (Noviria, M., 2014). Selain itu, pasien isolasi sosial juga biasanya menunjukkan sikap acuh dengan lingkungan, ekspresi wajah sedih, memisahkan diri dengan lingkungan, tidak peduli dengan lingkungan sekitar, posisi seperti janin tidur dan menolak berhubungan (Damaiyanti, 2012).

Hasil dari penelitian ini adalah kemampuan bersosialisasi klien sebelum diberikan latihan sosialisasi dan senam aerobik low impact di Lembaga Kesejahteraan Sosial (LKS) Mitra Sakti Kabupaten Pesawaran Provinsi Lampung mempunyai nilai rata-rata 5.2, setelah diberikan latihan sosialisasi dan senam aerobik low impact mempunyai nilai ratarata 11.6 dengan selisih rata-rata kemampuan bersosialisasi sebesar 6.4.

Hasil penelitian didukung pernyataan bahwa senam aerobik low impact dengan intensitas rendah berupa hentakan-hentakan ringan yang dilakukan teratur dapat meningkatkan kemampuan bersosialisasi (Noviria, M., 2014). Seseorang yang melakukan senam aerobik low impact dapat memperlancar aliran darah ke otak, persediaan nutrisi otak meningkat, metabolisme neurotransmiter dan seluler otak menjadi terjaga (Noviria, M., 2014). Hasil penelitian yang dilakukan sejalan dengan pernyataan bahwa terapi senam aerobik mempengaruhi keterbukaan diri pasien isolasi sosial di Rumah Sakit Jiwa Daerah (RSJD) Dr. Aminogondohutomo Semarang (Astuti, R. W., 2014).

\section{KESIMPULAN}

Hasil penelitian menunjukkan peningkatan kemampuan bersosialisasi setelah diberikan latihan sosialisasi dan senam aerobic low impact pada pasien skizofrenia yang mengalami isolasi sosial di Lembaga Kesejahteraan Sosial Mitra Sakti Kabupaten Pesawaran Provinsi Lampung. keterbukaan Diri Pada Pasien Isolasi Sosial Di RSJD Dr. Aminogondohutomo Semarang. Jurnal Ilmu Keperawatan dan Kebidananan (JIKK), Vol1, No1.

Damaiyanti. (2012). Asuhan Keperawatan Jiwa. Bandung: Refika Aditama.

Hambalda, I. (2018). Penerapan Prosedur Teknik Terapi Gerak Senam Aerobic Low Impact untuk Mengurangi Kekakuan Otot Pada Pasien Halusinasi. Karya Tulis Ilmiah. Program Studi DIII Keperawatan Fakultas Ilmu Kesehatan Universitas Muhammadiyah Perwokerto Tahun 2018.

Keliat, B. A.. (2014). Proses Keperawatan Kesehatan Jiwa, Edisi 2. Jakarta: EGC.

Yusuf, A.H., Fitriyasari, R dan Nirhayati, H.E. (2015). Buku Ajar Kesehatan Jiwa. Jakarta: Salemba Medika.

Noviria, Masnona et. al. (2014). Hubungan Dukungan Keluarga dengan Kunjungan Kontrol Pasien Jiwa Skizofrenia di Rawat Jalan Rumah Sakit Jiwa (RSJ) Provinsi Lampung Tahun 2013. Jurnal Kesehatan Holistik. Volume 8 (2): 76-81.

Nurhalimah (2016). Modul Bahan Ajar Cetak Keperawatan Jiwa. Jakarta: Kementerian Kesehatan Republik Indonesia.

Yosep, Iyus. (2013). Keperawatan Jiwa (Edisi Revisi). Bandung: Refika Aditama.

\section{DAFTAR PUSTAKA}

Astuti, R. W. (2014). Pengaruh Terapi Senam Aerobik Terhadap 